\title{
Are Young Physicians Have Problem in Job Insecurity? The Impact of Health systems' Changes
}

\author{
Luvy Kurniasari \\ PhD Student at Faculty of Psychology Airlangga University, Indonesia \\ luvy.enigma@gmail.com \\ Fendy Suhariyadi \\ Faculty of Psychology at Airlangga University, Indonesia \\ fendy.suhariadi@psikologi.unair.ac.id \\ Seger Handoyo \\ Faculty of Psychology at Airlangga University, Indonesia \\ seger.handoyo@psikologi.unair.ac.id
}

\begin{abstract}
Since 2013 Indonesia has adopted a national health system. This system changes directly affect the professional life of a physician. The system changes often lead to the rise of job insecurity on the individual involved. The purpose of this study is to investigate the impact of the health system's changes on young physician's job insecurity, based on the perception of payment, autonomy and meaningful work. The results of a literature review indicate that the factors that may affect the emergence of job insecurity are the perception of the payment and perceived autonomy. Research results show that Job Insecurity in physicians directly influenced by the perception of payment, the perception of autonomy and the meaningfulness of work, and then be indirectly affected by the perception of payment, the perception of autonomy with meaningfulness of work as mediation.
\end{abstract}

Keywords: Job insecurity, perception of payment, perceived autonomy, meaningful work, physician.

Received 29 December 2019/Accepted 28 February 2020 CJEHCP All rights reserved

\section{Introduction}

Population growth and the increase in life expectancy in Indonesia have resulted in various fields, one of which is the Increase in demand for health services. Increased demand for health services is made up of health facilities such as health centers and hospitals, as well as health professionals including physicians, but the number of physicians in Indonesia is not sufficient to provide optimal services (depkes.go.id). The ratio of physicians in Indonesia was 
30.98 per 100,000 people, while the ideal ratio is 40 per 100,000. Since 2014 , the Indonesian government held Health Insurance-National Social Security System (JKN) is a guarantee of health protection. The operations managed by the agency called BPJS (Social Security Provider). The existence of institutions BPJS changes the pattern of previous health care from clinical-based to social insurance-based (Fahmi Idris, 2008).

Changes in these systems led to the emergence of uncertainty among physicians. High demands on the role that carried by the physician, is not matched with the increase in welfare, unclear career paths and difficulty to access a higher level of education (specialist) physician put in a state of uncertainty. If the possibility of continuity of work is not clear, then the individual will be difficult to predict what will happen and how to behave (Lee ,dkk. dalamLoi, Lam, \& Chan, 20I2). Besides that, someone will feel they have no power to control the potential threat. System changes are one of the causes of the phenomenon of job insecurity. The purpose of this study was to identify factors that lead to job insecurity in physicians. Job insecurity has been known to harm the individual, blue collar employees, contract employees (Martínez, Cuyper, \& De Witte, 2010; Richter, Näswall, BernhardOettel, \& Sverke, 20I3), but not many studies focus on the antecedent of job insecurity, specifically among young physicians.

Previous research shows that insecure is experienced by individuals from various backgrounds work, including ever observed was attorney law firm, bank clerks and employees in industry (J. P. Briscoe, Henagan, Burton, \& Murphy, 2012; Konig, Debus, Hausler, Lendenmann, \& Kleinmann, 20I0; Staufenbiel \& König, 20II). But, until now special research to study job insecurity on the physician is not found.

Job Insecurity and Professional Life of Physicians

Job insecurity $(\mathrm{II})$ is defined as a perception of helplessness or powerlessness to maintain a work environment that is considered threatening. Job insecurity is psychological discomfort because of the inability to predict aspects of work in the future, consider to be threatening, in terms of lost profits and tend to lose positives benefits like money, social factor ad 
psychological condition (Greenhalgh \& Rosenblatt, 1984, 2014). Job insecurity arises based on individual perceptions and interpretations of the work environment.

On the situation faced by physicians, change in the health care system is the objective situation must be faced, but these changes can be interpreted differently Physicians differ in to determine whether the extent of the change is considered to be a threat/danger or not. A physician who interpreted the change as something that is not threatening, have the possibility not experiencing job insecurity, but if the changes are perceived threaten the sustainability of the profession in the future, the individuals concerned have the potential to experience job insecurity. Job insecurity in the context of this research is reviewed as a stressor based approach to the theory of stress, assuming the impact of the implementation of the new health care system by BPJS potential to cause uncertainty and helplessness physicians concerning the future of his career. Research on the medical profession in the context of the relevant stress theory perspective is done, the data showed $15-20 \%$ of a physician are having problems with their mental health during a certain time in his professional life (Epstein \& Krasner, 2013; Zwack \& Schweitzer, 20I3). Research carried by Grassi \&Magnani (2000) shows, physicians showing symptoms of stress, work stress and burnout were higher than the average individual in the population (Sochos, Bowers, \& Kinman, 2012).

The physician with tenure of fewer than 10 years or also called junior physicians become a study of research on the assumption that those who are responsible in the health center are a GateKeeper for the implementation of JKN. Research conducted by Sigh (2000) shows that the newly graduated physician/juniors have high levels of stress than senior physicians. This is due to the career orientation is very high, it has a very strong desire for immediate success, but due to lack of promotion opportunities and feeling insecure work still causing prolonged stress on junior physicians. The more junior physicians feel stressed by his job, the more negative aspects of perceiving the work, particularly relating to senior physicians/consultants/specialists. Junior physicians did not get the recognition of the seniors and find it difficult to be able to interact well (Singh, 2000). 
The Aspect that underlies the emergence of job insecurity is powerlessness. Powerlessness (powerlessness) include the inability to eliminate sustainability work. Research by Gask (2004) showed more and more physicians who feel helpless (powerlessness) related to the profession. Sources of powerlessness which this is a feeling of isolation, limited role in decision-making autonomy (reduced), working hours are too long, undervalued, reduced function of the team is effective, too many administrative tasks, demands that conflict and the unavailability of time to think, speak or reflection, lack of clarity in the work and the career opportunities that are not clear (Gask, 2004). Job insecurity is one stressor at work that is considered the most important because it affects the whole of the feelings, attitudes, and behaviors of individuals, not merely affect performance (Keim, Landis, Pierce, \& Earnest, 2014), The conclusion of the various definitions are then summed job insecurity is a condition experienced by individuals who feel uncertain about the future of their profession, are subjective and the uncertainty arises from the observation of the work environment changes.

Hans De Witte state that job insecurity has two dimensions: Cognitive Jl was cognition elements of individual experiences relating to the possibility of losing their jobs or income. Affective Jl was the emotional element of the experience of the individual against the possibility of losing a job or income (Urbanavičiūtè, Bagdžiūnienè, Lazauskaitè-Zabielskè, Elst, \& De Witte, 20I5).

\section{Perception of payment}

The physicians are the spearhead of health care. The behavior of physicians in practice will influence the selection of treatment, quality, and price or issued from the health service, Aspects of financial incentives in the form can quickly motivate physicians to provide services, improve work efficiency and can increase empathy for patients (Ran, Luo, Wu, Yao, \& Feng, 2013). Research conducted against the new physician who graduated from the Polish by Balonowski found presence 7 factors trigger AAF (anxiety about professional Future) physicians (Bolanowski, 2005). Seven factors include a). Salary/low revenue b) The negative impact of work on family life. c) Stress overload. In countries that are reforming the health, sector found many physicians who are experiencing stress. The main cause of stress 
is the inability to follow the new regulations are deemed unreasonable, lack of resources to meet the needs of the patient as well as the required number of patients who are too much. d) lack the resources to cope with stress. The ability of individuals to be able to cope with stress vary. The impact of the inability to manage stress can be varied, ranging from errors in diagnosis and cause of death due to malpractices .e) Limitations to grow professionally (both financial and institutional) and $\mathrm{f}$.

Evolution of the role and status of physicians.

Until now some countries are still seeking payment deemed most appropriate for the physicians (Grignon, Paris, \& Polton, 2002; ) This is because since the implementation of insurance-based healthcare system implemented, many physicians feel less satisfied with their profession(Kaplan, 2009; Michaelson, Pratt, Grant, \& Dunn, 2014), Research conducted in China showed the majority of physicians who becomes the object of the study was not satisfied with the income received. compensation considered low and unfair with their expertise is the main factor that causes declining enthusiasm for work(Kuusio, Heponiemi, Aalto, Sinervo, \& Elovainio, 20I2).

\section{Perceived Autonomy}

In the medical profession, the main element of autonomy is the certainty that the physicians has the freedom to use the professional judgment in determining the type of treatment or care given to patients(Hashimoto, 2006), Autonomy for physicians means that physicians have the freedom to determine the type of treatment that best suits the needs of patients to achieve well-being, To achieve autonomy, physicians are required to have the technical competence to perform the examination (Emanuel \& Pearson, 2012), This time the physicians have the autonomy which is much lower than autonomy has ever had in previous decades (Warren, Weitz, \& Kuhs, 1999), This change is caused by two things: a). Increased government efforts to control costs associated with health problems, such as the maximum set rules regarding the cost of diagnosis. b) Increased awareness to be an insurance-based health care member. 


\section{Meaningful work}

Meaningfulness of work according to Chalofsky is the meaning of work is not just about the meaning of the paid work we perform; it is about the way we live our lives. It is the alignment of purpose, values, and the relationships and activities we pursue in life ... It is about integrated wholeness". The views Chalofsky stressed the importance of integration between the goals, values, and relationships to achieve wholeness (Chalofsky, 20I0), Another opinion expressed by Fairlie stating meaningful work is defined as a job and other workplace characteristics that Facilitate the Attainment or maintenance of one or more dimensions of meaning". Meaningful is work together with the characteristics of a workplace that facilitates the achievement or the preservation of one or more dimensions of meaningfulness (Fairlie, 20II). Meaningful work is a subjective condition derived from the positive level of overall associated with a job. When a person feels the work is meaningful, then people will associate something positive concerning it, for example, perceived work or while doing work (Yeoman, 20I4).

The individual's perception that the job meaningful or aims and does his job wholeheartedly is the most important characteristic of the meaningfulness of work that is often referred to as the call (the calling). An initial survey of physicians conducted by researchers showed the desire of respondents chose the medical profession for reasons of heart calls (16\%). Results of research conducted by Wrzeniewski (2010) shows a person who feels that his job is a form of heart shorter calls, have higher job satisfaction, feeling freer, and do not mind the time and effort in working (MF Steger, sister, \& Duffy, 2012). The ability of a person to be able to find significance in his work will determine the extent to which the party concerned has the potential to experience psychological distress or otherwise, experienced well-being. The results showed that physicians who are trained to find significance in his work, is relatively reduced distress, and more involved in its work (West, et al., 2014).

Results of other studies indicate that even though the individual perceives himself paid below the average, working discontent will not appear if an individual feels his work in a secure position (Narisada \& Schieman, 2016). Based on these descriptions, the researchers suspect that the perception against payment (payment) influence on the rise of job insecurity 
on the physicians. Meaningfulness of work serves as a barrier (buffer) job insecurity with the assumption that someone who feels his work is meaningful, always feel have complete control of himself and his work. As stated by Lips-Wiersma \& Wright (2016), individuals who interpret the work will have autonomy and control over what (Lips-Wiersma, Wright, \& Dik, 2016) If based on the statement that could otherwise interpret the individual who will work plenipotentiary to their work, do not feel the perception of reduced autonomy and confident in doing their jobs because interpret the work in accordance with the values held. If the people who interpret the work as aforesaid, the researchers assume the meaningfulness of the work will be retaining (buffer) for the job insecurity due to job insecurity generally arise in situations where individuals feel they have no control over him (Barling \& Kevin, 1996).

\section{Research Model}

Based on the below model is known that Job Insecurity in physicians directly influenced by the perception of payment $(X I)$, the perception of autonomy $(X 2)$ and the meaningfulness of work ( $\mathrm{ZI})$, and then be indirectly affected by the perception of payment $(X I)$, the perception of autonomy (X2) with meaningfulness of work as mediation. In ensuring the relationship model, then used the method of analysis Structural Equation Modeling (SEM). Furthermore, referring to the model, the following research hypothesis:

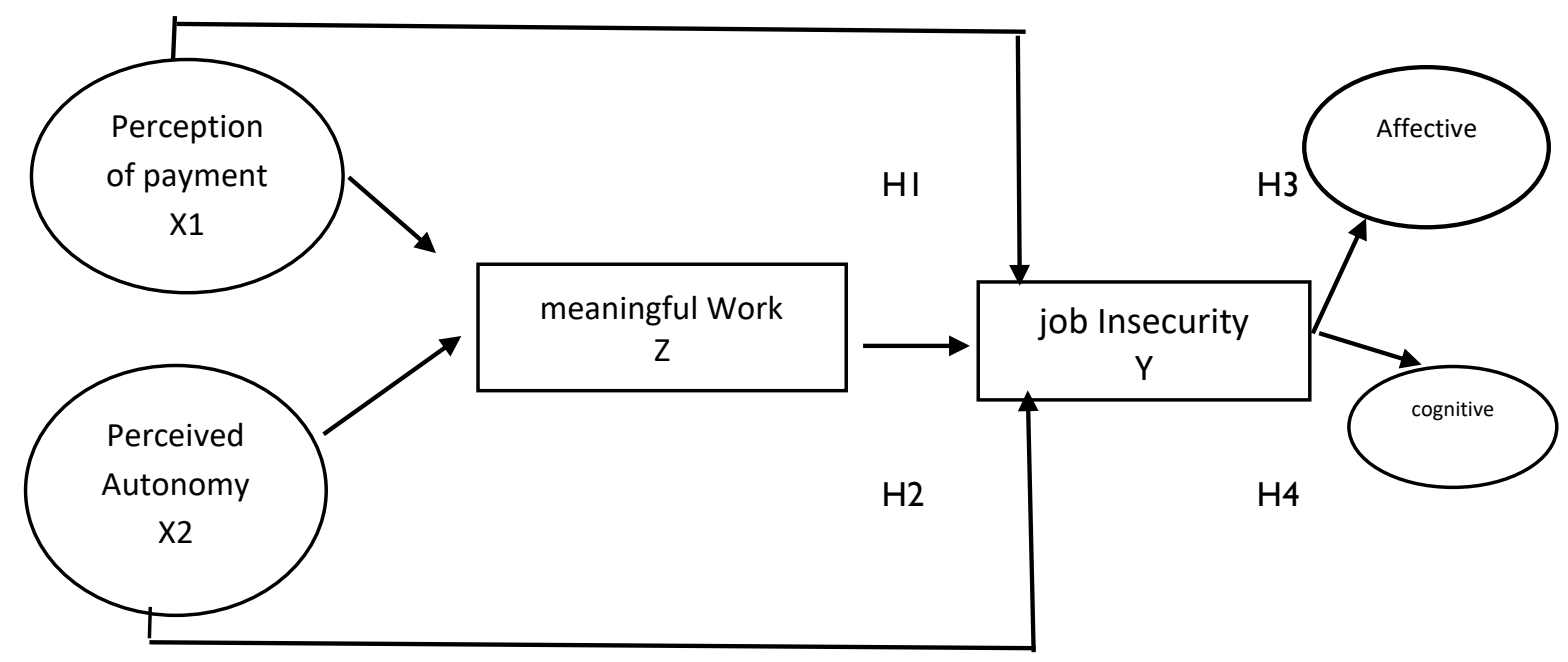

Fig I. A proposed model of Job Insecurity in terms of Physician Payment Perception, perceived Autonomy with Meaningfulness Mediation Work 


\section{Hypothesis}

$\mathrm{HI}$ : There is a perception effect payment $(\mathrm{XI})$ against job insecurity in the physician $(\mathrm{Y})$, either directly or indirectly through the meaningfulness of work as a mediation $(\mathrm{ZI})$; $\mathrm{H} 2$ : There is a perception influences autonomy $(\mathrm{X} 2)$ against job insecurity in the physician $(Y)$, either directly or indirectly through the meaningfulness of work as a mediation $(\mathrm{ZI}) ; \mathrm{H} 3$ : Job Insecurity on general practitioners $(Y)$ is explained by cognitive factors Job Insecurity (YI) ; H4: Job Insecurity on general practitioners (Y) is described by affective factors Job Insecurity (Y2).

\section{Method}

\section{Design Research}

This study uses a quantitative approach with a survey method. The variables that will be studied consist of payment perception variables, perceptions of autonomy variables, job insecurity variables and work meaningful variables. All variables are measured using an instrument in the form of a questionnaire.

\section{Participants}

The sample consisted of young physicians who were employed in Puskesmas (community health center). The number of respondents was 217 physician, in Surabaya, Indonesia. In this study, the term junior physicians refers to Tomioka's study which limits junior physicians to doctors who have not taken a specialization program with a tenure of fewer than 10 years (Tomioka, Morita, Saeki, Okamoto, \& Kurumatani, 20lI) There are several reasons for using 10 years of experience. First, young physicians experiencing system change, and also tend to experience Anxiety for the Future (Bolanowski, 2005) and also lack control and have minimum strategies for coping (Gask, 2004). Demography delivered which includes gender, age, status, current college tuition, work, employment status, and long working as a physician.

Physician surveys were distributed to randomly selected to the physician who had been working for a maximum of 10 years. The process began with an explanation of the study's 
objectives. Physicians were advised that participation was voluntary and that their responses would remain anonymous. Survey questionnaires originally written in English were translated into Indonesia via the back-translated method. The completed questionnaires were sealed in envelopes to ensure anonymity and collected by the researcher two weeks later. Questionnaires were distributed to 250 physicians and back 217.

Table I

Demographic Characteristics of Respondents

\begin{tabular}{|c|c|c|c|}
\hline V ariable & Atributtion & Frequency & Prosentages \\
\hline \multirow[t]{3}{*}{ Dl.Sex } & Male & 74 & $34.1 \%$ \\
\hline & Female & 143 & $65.9 \%$ \\
\hline & 'I'otal & 217 & $100.0 \%$ \\
\hline \multirow[t]{7}{*}{ D2.Age } & $25-30$ & 93 & $42.9 \%$ \\
\hline & $31-35$ & 42 & $19.4 \%$ \\
\hline & $36-40$ & 26 & $12.0 \%$ \\
\hline & $41-45$ & 23 & $10.6 \%$ \\
\hline & $46-50$ & 18 & $8.3 \%$ \\
\hline & $>50$ & 15 & $6.9 \%$ \\
\hline & 'Total & 217 & $100.0 \%$ \\
\hline \multirow[t]{3}{*}{ D3.Status } & Single & 64 & $29.5 \%$ \\
\hline & Married & 153 & $70.5 \%$ \\
\hline & 'Total & 217 & $100.0 \%$ \\
\hline \multirow[t]{3}{*}{ D4.University status } & P'IN & 92 & $42.6 \%$ \\
\hline & PTS & 124 & $57.4 \%$ \\
\hline & 'lotal & 216 & $100.0 \%$ \\
\hline \multirow[t]{3}{*}{ D5.Employee Status } & PNS & 88 & $40.6 \%$ \\
\hline & Honorer & 129 & $59.4 \%$ \\
\hline & 'Total & 217 & $100.0 \%$ \\
\hline \multirow[t]{5}{*}{ D6.Length of work } & $0-3$ years & 77 & $35.5 \%$ \\
\hline & 4-7 years & 43 & $19.8 \%$ \\
\hline & $8-11$ years & 36 & $16.6 \%$ \\
\hline & $>11$ years & 61 & $28.1 \%$ \\
\hline & Total & 217 & $100.0 \%$ \\
\hline
\end{tabular}

\section{Measurements}

The questionnaire consisted of 5 parts. The first part contained questions about participants' demographic information (e.g., age, gender) and job-related information (e.g., tenure, position). The second part requested physicians to rate their overall recognition of Job insecurity, the authors use the modification Scale of JII (Job Insecurity Inventory) from Hans 
De Witte (Pienaar, De Witte, Hellgren, \& Sverke, 2013; Vander Elst, De Witte, \& De Cuyper, 2014) to measure two dimensions of job insecurity, cognitive job insecurity and affective job insecurity, especially for physician job.

Perception of payment. Physician's perception towards the payment (payment), was measured by using a sub-scale Perceptions of Payments compiled by Konrad (1999). Indicators of perception to include perceptions of income payments (direct pay), perceptions of the benefits and perceptions of financial security in the future. The original contents of the questionnaire given to respondents is as follows:"l earn enough to provide for my children and their future education, My prospects for future financial security are bright, My total compensation package is fair".

Table 2

Statistical Value of Test Validity and Reliability Tests for Measurement Models Payment

\begin{tabular}{lcc}
\hline $\begin{array}{c}\text { Dimension of } \\
\text { Payment }\end{array}$ & $\begin{array}{c}\text { Item } \\
\text { Validity test }\end{array}$ & $\begin{array}{c}\mathrm{M}(7) \\
\text { Loading factor }\end{array}$ \\
\hline Income & $\mathrm{Pa} 3$ & 0.86 \\
& $\mathrm{~Pa} 6$ & 0.96 \\
Benefit & $\mathrm{Pa} 4$ & 0.72 \\
& $\mathrm{~Pa} 7$ & 0.73 \\
Financial Security & $\mathrm{PaI}$ & 0.61 \\
& $\mathrm{~Pa} 2$ & 0.80 \\
& $\mathrm{~Pa} 5$ & 0.72 \\
Payment & Reliability & \\
income & $\mathrm{AVE}$ & value \\
& $\mathrm{CR}$ & 0.82 \\
Benefit & $\mathrm{AVE}$ & 0.90 \\
& $\mathrm{CR}$ & 0.53 \\
Financial Security & $\mathrm{AVE}$ & 0.69 \\
& $\mathrm{CR}$ & 0.51 \\
& & 0.75 \\
\hline
\end{tabular}

Perceived Autonomy. Scale perceptions of physician autonomy are measured using a Subscale of Autonomy of physicians from Konrad (Konrad et al., 1999) which has been translated. Indicators of perceived autonomy are having control in making important decisions and authority inpatient care based on the best clinical judgment. The original contents of the 
questionnaire given to respondents is as follows. "I am able to provide the full range of services for which I am trained, I am able to set the pace of my own work. I am able to set the pace of my own work".

Table 3

Statistical Value of Validity Test and Reliability Test of 2 Models of Measurement of Perception of Autonomy

\begin{tabular}{lcc}
\hline Dimension & Item question & $\begin{array}{l}\text { M(6) } \\
\text { Loading factor }\end{array}$ \\
\hline Perception of autonomy & Validity test & 0.78 \\
Freedom & Otl & 0.81 \\
& Ot2 & - \\
& Ot3 & 0.54 \\
& Ot5 & - \\
& Ot6 & - \\
Time & Ot7 & - \\
& Ot8 & 0.76 \\
Communication & Ot4 & 0.73 \\
Perception of autonomy & Ot10 & \\
Freedom & & \\
& Reliability test & 0.52 \\
Time & AVE & 0.76 \\
& CR & 0.57 \\
Communication & AVE & 0.57 \\
& CR & 0.50 \\
& AVE & 0.66 \\
\hline
\end{tabular}

Meaningful work. Measurement significance of the work is done by using a scale created by Steger (20I2), Wami (The Work and Meaning Inventory). The four scale based on the Likert scale. Likert Scale is one technique to measure attitudes, opinions, and perceptions of the subject. The reason researchers used a Likert scale because (a) easier to make (b) relatively high reliability (c) provide information that is more realistic and clear about opinions or attitudes of respondents on the issue in question (Nazir, 2005). These scales exist that contain items favorable and unfavorable. Favorable items are statements that support the object, whereas unfavorable items are statements that are unfavorable to the 
object. The original contents of the questionnaire given to respondents is as follows "I have found a meaningful career, I view my work as contributing to my personal growth,My work really makes no difference to the world".

Table 4

Statistical Value of Validity Test and Reliability Test of Measurement Model Perception of Meaningfulness of Work

\begin{tabular}{lll}
\hline Dimension & Item & M(I0) \\
Meaningful work & Validity test & Loading factor \\
\hline Psychological Meaningful & KKI & 0.84 \\
& KK2 & 0.96 \\
& KK7 & 0.52 \\
Meaning Making & KK3 & \\
& KK4 & 0.87 \\
KK5 & 0.97 \\
KK8 & 0.93 \\
Greater Good & KK6 & 0.94 \\
& KK9 & 0.90 \\
& KKI0 & 0.90 \\
& & 0.84
\end{tabular}

Table 5

Reliability test

\begin{tabular}{lcl}
\hline & Reliability test & value \\
\hline Psychological & AVE & 0.63 \\
Meaningful & & \\
& CR & 0.83 \\
Meaning Making & AVE & 0.86 \\
\multirow{2}{*}{ Greater Good } & CR & 0.96 \\
& AVE & 0.77 \\
& CR & 0.91 \\
\hline
\end{tabular}

Data analysis

This research model is a causal model with exogenous variables and multiple endogenous variables (more than one), so to complete the analysis of data using the Structural Equation Modeling (SEM) method. The SEM method is a statistical analysis for multivariate data that 
aims to obtain a causal model using a combined approach between the Confirmatory Factor Analysis (CFA) method and the Path Analysis method. Data analyzed in the SEM method is Covariances Based Data (CBD), which is a collection of data matrices that contain covariance values. Furthermore, for data processing with the SEM method using the help of Lisrel software.

\section{Result}

Determining the Goodness of Fit (GOF) SEM Model

Before testing the indicator confirmation of the factors by testing the measurement model, and before testing the path of the relationship between factors by conducting structural testing. Then it checks the goodness of the SEM model by looking at the value of goodness of fit. An SEM model is called fit if it meets several index criteria of goodness of fit, along with the criteria

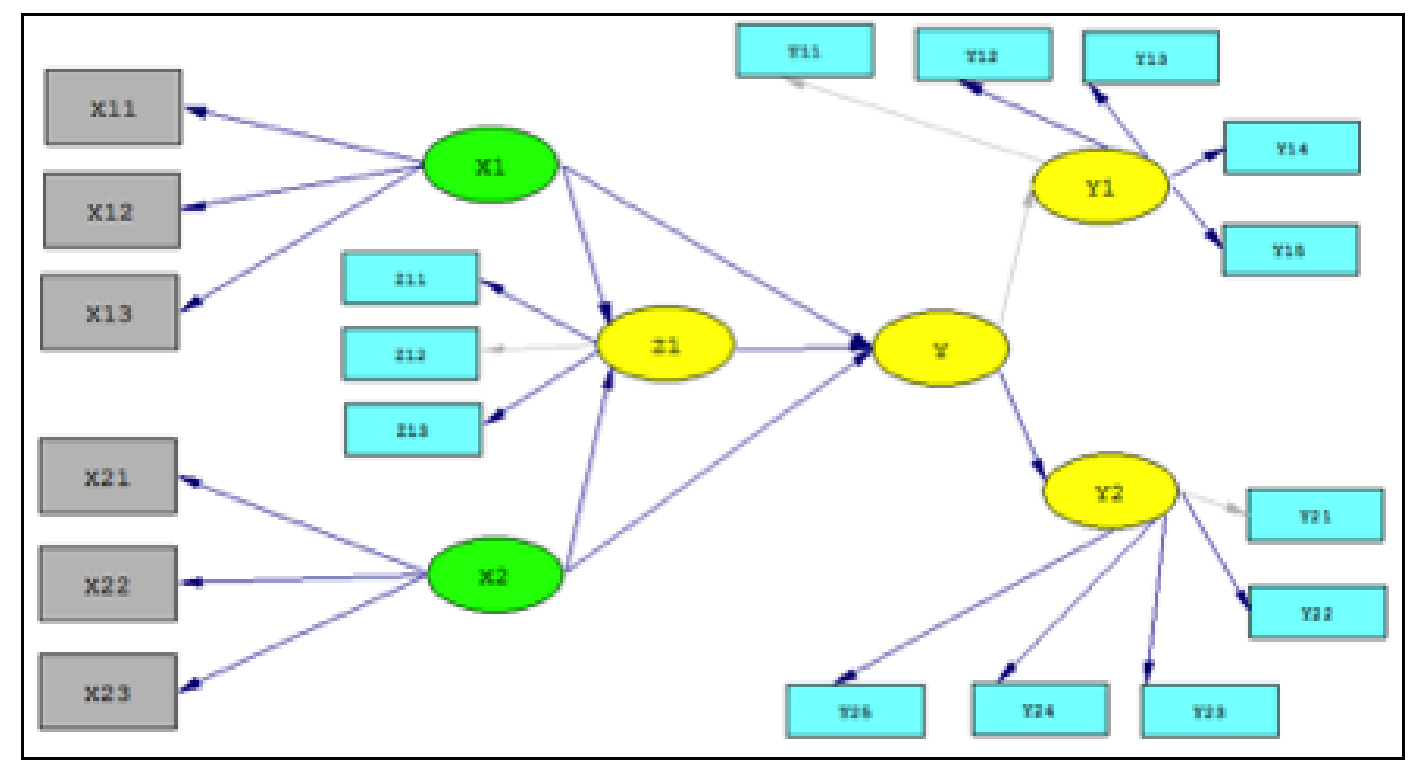

Fig 2. Model Physician Job Insecurity in terms of Perception of Payment, Perceived Autonomy with Meaningfulness work as a mediator

\author{
XI: Perception Payment \\ YI: Job Insecurity Cognitive \\ XII: Perceptions of income \\ YII: Feelings trouble get a job
}

XI2: Perceptions of benefit

YI2: Feelings Low income

XI3: Perceptions of financial security

YI3: Feelings stress to the working environment 
X2: Perception of Autonomy

Y I4: Feelings poorly developed into a specialist

X21: Freedom

Y 15: Feelings the decreasing role of the physicians

$X 22$ : Time interaction elbow

Y2: Job Insecurity Affective

X23: Communication

Y2I: Emotions difficulty to get a job

ZI: Significance of Work
Y22: Emotions Low income

ZII: Psychological meaningfulness in work

Y23: Emotions stress to the working environment

Z12: Making Meaning through work

Y24: Emotions poorly developed into a specialist

ZI3: Greater good motivation

Y25: Emotions the decreasing role of the physicians

Y: Job Insecurity

Based on the visual image on figure 2, it can be seen that the SEM model is depicted in a circle and rectangular shape. The shape of a circle is a factor/construct / unobserved variables where these variables are measured or explained by observed variables (indicators). The rectangular shape is an indicator (observed variables) where the value of this variable is obtained from the measurement data (observation). Based on the SEM model picture above, 3 factors are explained by $X I$ factors, then 3 indicators are explained by $X 2$ factors, 3 indicators are explained by $X 3$ factors, 3 factors by $\mathrm{ZI}$ factors are explained by 5 indicators by $\mathrm{Y} I$ factor, and 5 factors are explained by $\mathrm{Y} 2$ factors.

Table 5.

Criteria for the index value Goodness of Fit models

\begin{tabular}{ll}
\hline Value Goodness of Fit $(\mathrm{GoF})$ & Criteria index \\
\hline Chi Square $(\lambda 2)$ & $\begin{array}{c}\text { The value of chi square count } \\
<\text { value table } \lambda 2(\alpha ; \mathrm{df})\end{array}$ \\
Sig. probability & Sig. $\begin{array}{l}\geq 0.05 \\
\text { RMSEA }\end{array}$ \\
GFI & RMSEA value $\leq 0.05$ \\
AGFI & GFI value $\geq 0.90$ \\
CFI & AGFI value $\geq 0.90$ \\
\hline
\end{tabular}

Based on the results of processing with Lisrel software. The following GoF values obtained from the final model SEM, which is then compared to a GoF criteria values. 
Table 6

Comparison of Goodness of Fit with index criteria

\begin{tabular}{llll}
\hline \multicolumn{1}{c}{ Value Goodness of Fit(GoF) } & \multicolumn{1}{c}{ criteria index } & Value goodness of fit & Information \\
\hline Chi Square $(\lambda 2)$ & $\begin{array}{l}\text { The value of chi } \\
\text { square count }<\text { value table } \\
\end{array}$ & $15 I .2<169.7$ & Model fit \\
& Sig. $\geq 0.05$ & & \\
Sig. probability & RMSEA value $\leq 0.05$ & $\leq, 264 \geq 0.05$ & Model fit \\
RMSEA & GFI value $\geq 0.90$ & $0.935 \geq 0.90$ & Model fit \\
GFI & AGFI value $\geq 0.90$ & $0.919 \geq 0.90$ & Model fit \\
AGFI & CFI value $\geq 0.90$ & $0.94 I \geq 0.90$ & Model fit \\
CFI & & Model fit \\
\hline
\end{tabular}

Based on the results of processing with Lisrel software. The following GoF values obtained from the final model SEM, which is then compared to a GoF criteria values.Based on the comparison in table 6, are known to all grades GOF meet the criteria. Thus concluded the job insecurity physician model in terms of the perception of payment, perceived autonomy with meaningfulness mediation works, a fit model. this means that models are made in conformity with the existing data. Referring to the test results of model fit (goodness of fit model), the following is the result of a physician model of job insecurity seen from the perception of payment and perceived autonomy with the mediation of meaningfulness of work.

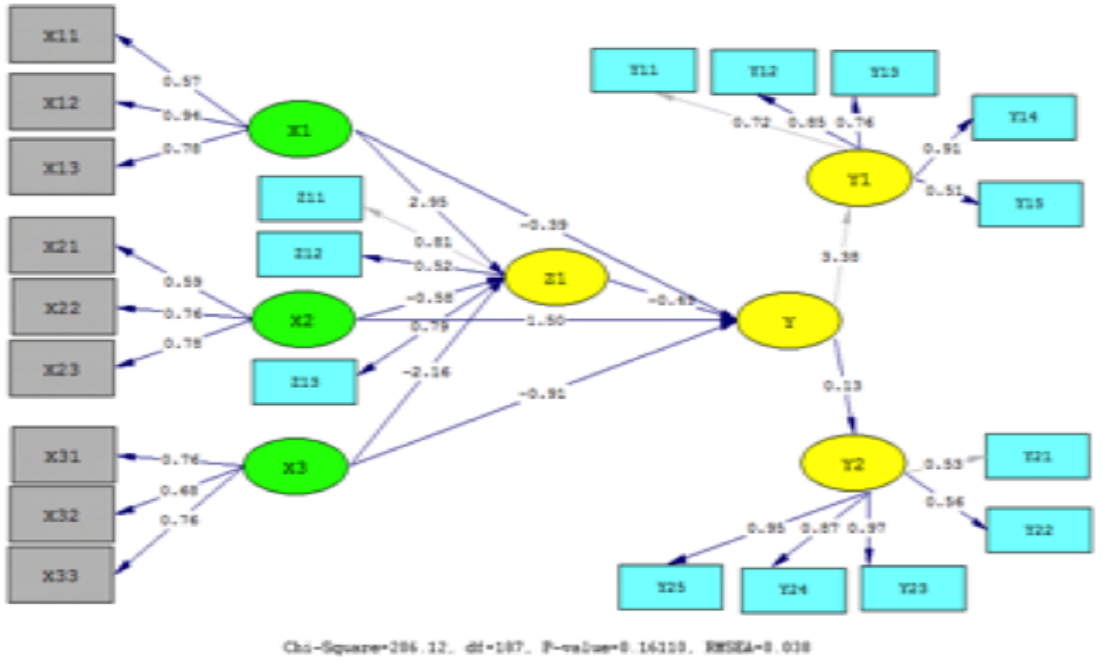

Fig 4. SEM Physicians's Job Insecurity: Standardized Estimated 


\author{
XI: Perception Payment \\ YI: Job Insecurity Cognitive \\ XI I: Perceptions of income \\ YII: Feelings difficulty to get a job \\ $X$ I2: Perceptions of benefit \\ Y I2: Feelings Low income \\ $X$ I3: Perceptions of financial security \\ YI3: Feelings stress to the working environment \\ $\mathrm{X}$ : Perception of Autonomy \\ Y|4: Feelings poorly developed into a specialist \\ $\mathrm{X} 21$ : Freedom \\ YI5: Feelings the decreasing role of the physicians \\ $\mathrm{X} 22$ : Time interaction elbow
}

\author{
Y2: Job Insecurity Affective \\ $\mathrm{X} 23$ : Communication \\ Y2 I: Emotions difficulty get a job \\ ZI: Significance of Work \\ Y22: Emotions Low income \\ ZI I: Psychological meaningfulness in work \\ Y23: Emotions stress to the working environment \\ ZI2: Making Meaning through work \\ Y24: Emotions poorly developed into a specialist \\ ZI3: Greater good motivation \\ Y25: Emotions the decreasing role of the physicians \\ Y: Job Insecurity
}

Based on the SEM model results with the estimated standards above, it is known the estimated value of a constructed variable (circular figure) against the indicator variable (square), these values will be discussed further in the measurement model analysis. Furthermore, it is also known the estimated value of the relationship of influence between the exogenous construct (green circle) and endogenous construct (yellow circle), these values will be discussed later in the structural model analysis.

Tests Confirmation Indicator of Factor (Measurement Model)

Tests confirm indicator of the factors by using Confirmatory Factor Analysis (CFA). CFA's purpose is to test the validity and reliability factors. Factor in SEM models grouped into factors exogenous and endogenous factors, in which exogenous factors are factors that affect the endogenous factor, whereas endogenous factors are factors that are influenced by exogenous factors. 
Table 7

The results of the validity and reliability of exogenous factors

\begin{tabular}{lllcc}
\hline \multicolumn{1}{c}{ Exogenous factors } & Indicator & $\begin{array}{c}\text { Loading } \\
\text { Factor }\end{array}$ & $\begin{array}{c}\text { Average } \\
\text { Variance } \\
\text { Extracted } \\
\text { (AVE) }\end{array}$ & $\begin{array}{c}\text { Composite } \\
\text { Reliability } \\
\text { (CR) }\end{array}$ \\
\hline XI.Perception of Payment & XII.direct payment & $0: 57$ & $0: 57$ & 0.80 \\
& X12.Benefit & 0.92 & & \\
& X13. Financial Security & 0.74 & & \\
X2. Autonomy perception & X21.Freedom & & $0: 51$ & 0.75 \\
& X22.Time interaction & & & \\
& X23.communication & 0.67 & & \\
\hline
\end{tabular}

Based on table 7, it can be concluded that the exogenous factors $X I$ and $X 2$ are known all factor loading value of the indicator is more than 0.5 because they meet the validity criteria, we conclude exogenous factors $X I$ and $X 2$ are validly described by the indicators. Furthermore, the value AVE of exogenous factors $X I$ and $X 2$ which are both worth more than 0.5 . Then reinforced with the $C R$ value of more than 0.6 . Due to reliably meet the criteria, we conclude factor $\mathrm{XI}$ and $\mathrm{X} 2$ are reliable.

Based on the above factors are known as sequence loading weight values of the indicators of the factor. Payment factor perception's greatest value comes from the perception of benefit $(X \mid 2)$, then financial security $(X \mid 3)$, and the perception of income $(X \mid 3)$. Autonomy perception factor weighting the greatest value comes from the perception of the interaction time (X22), then freedom (X21), and communication (X23) where value is the same. 
Tabel 8

Validity and reliability of edogenous factors

\begin{tabular}{|c|c|c|c|c|}
\hline $\begin{array}{l}\text { Endogenous } \\
\text { factors }\end{array}$ & Indicator & $\begin{array}{l}\text { Loading } \\
\text { factor } \\
\text { (LF) }\end{array}$ & $\begin{array}{l}\text { Average } \\
\text { Variance } \\
\text { Extracted } \\
\text { (AVE) }\end{array}$ & $\begin{array}{c}\text { Composite } \\
\text { Reliability } \\
\text { (CR) }\end{array}$ \\
\hline $\begin{array}{l}\text { Meaningful } \\
\text { Work ZI. }\end{array}$ & $\begin{array}{l}\text { X21. Psychological meaningfulnes in work } \\
\text { X22. Making Meaning through work } \\
\text { X23. Greater good motivation }\end{array}$ & $\begin{array}{l}0.83 \\
0: 53 \\
0.81\end{array}$ & $0: 54$ & 0.77 \\
\hline $\begin{array}{l}\text { YI. } \\
\text { Cognitive } \\
\text { Job } \\
\text { Insecurity }\end{array}$ & $\begin{array}{l}\text { YII. Trouble getting a job } \\
\text { YI2. Low income } \\
\text { YI3. Stress to the working environment } \\
\text { YI4. The lack of opportunity to develop } \\
\text { (become specialists) } \\
\text { YI5. The decreasing role of the physicians } \\
\text { (due to complex bureaucracy }\end{array}$ & $\begin{array}{c}0.88 \\
0.72 \\
0.5 \\
0.8 \\
0: 55\end{array}$ & $0: 50$ & 0.83 \\
\hline $\begin{array}{l}\text { Y2. } \\
\text { Affective } \\
\text { Job } \\
\text { Insecurity }\end{array}$ & $\begin{array}{l}\text { Y21. Trouble getting a job } \\
\text { Y22. Low income } \\
\text { Y23. Stress to the working environment } \\
\text { Y24. The lack of opportunity to develop } \\
\text { (become specialists) } \\
\text { Y25. The decreasing role of the physicians } \\
\text { (due to complex bureaucracy }\end{array}$ & $\begin{array}{c}0: 51 \\
0: 55 \\
0.93 \\
0.85 \\
0.9\end{array}$ & $0: 59$ & 0.87 \\
\hline
\end{tabular}

\section{Result}

Based on table 8, it can be concluded that the endogenous factors $\mathrm{ZI}, \mathrm{YI}$, and $\mathrm{Y} 2$ are meet the validity criteria, we conclude endogenous factors $\mathrm{ZI}, \mathrm{YI}$ and $\mathrm{Y} 2$ is valid are described by the indicators. Due to reliably meet the criteria, we conclude endogenous factors ZI, YI, and $Y 2$ are reliable.Based on the above factors are known as sequence loading weight values of the indicators of the factor. Factors meaningfulness of work (ZI) the greatest value comes from psychological meaningfulness in work (ZII) and Greater good motivation (ZI3) where value is relatively the same, Then the new Making Meaning through work $(Z \mid 2)$. Cognitive factors of job insecurity (YI) the greatest value comes from cognitive difficulties getting a job (YII), then both the cognitive lack of opportunity to develop become a specialist $(Y \mid 4)$, third cognitive low income $(Y \mid 2)$, the four cognitive increasingly reduced role of the physicians as a result of bureaucracy complex (YI5), and the five cognitive stress of the work environment (YI3). Affective factors of job insecurity (Y2) the greatest value 
comes from the emotional stress of the work environment (Y23) and tempers are getting a reduced role of the physicians as a result of bureaucracy (Y25) where value is relatively the same, both emotional lack of opportunity to develop into a specialist (Y24), three emotions a low income (Y22), and emotional difficulties getting a job (Y2I) where value is relatively the same.

Testing the Relationship Path between Factors (Structural Model Testing)

Testing the path of the relationship between factors is done to evaluate the significance of the relationship between exogenous factors to endogenous factors. The results are used to answer the research hypothesis. The testing using t-test with the testing criteria, Comparing the value of $t$-statistics processing results compared with $t$-table value. If the value of $\mid t-$ statistics $\mid \geq \mathrm{t}$-table then it can be concluded that there is a significant effect of exogenous factors on the relationship between endogenous factors, and vice versa. T-test was used two-way (two tail) With an error tolerance level $\alpha=5 \%$, the number of data samples 217 respondents then obtained the value of table $t=t(\alpha / 2, n-I)=t(5 \% / 2.216)$ of 1.97. Here is the visually value of the t-statistics test result processing model line job insecurity in physicians seen from the perception of payment, with the mediation of meaningfulness of work autonomy.

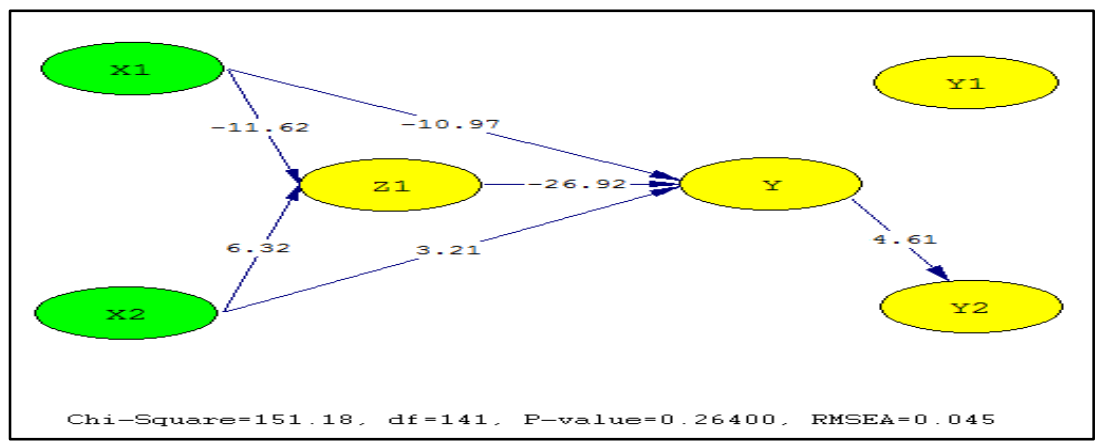

Fig 5. Value t-statistics on the relationship path between factors

Based on figure 5 , the value of the t-statistics direct relationship between the variables, which are marked in the arrow direction. Conclusion the test results of the relationship, more in the table below. 
Table 9

Results of testing the influence of exogenous factors on endogenous factors in relationlane

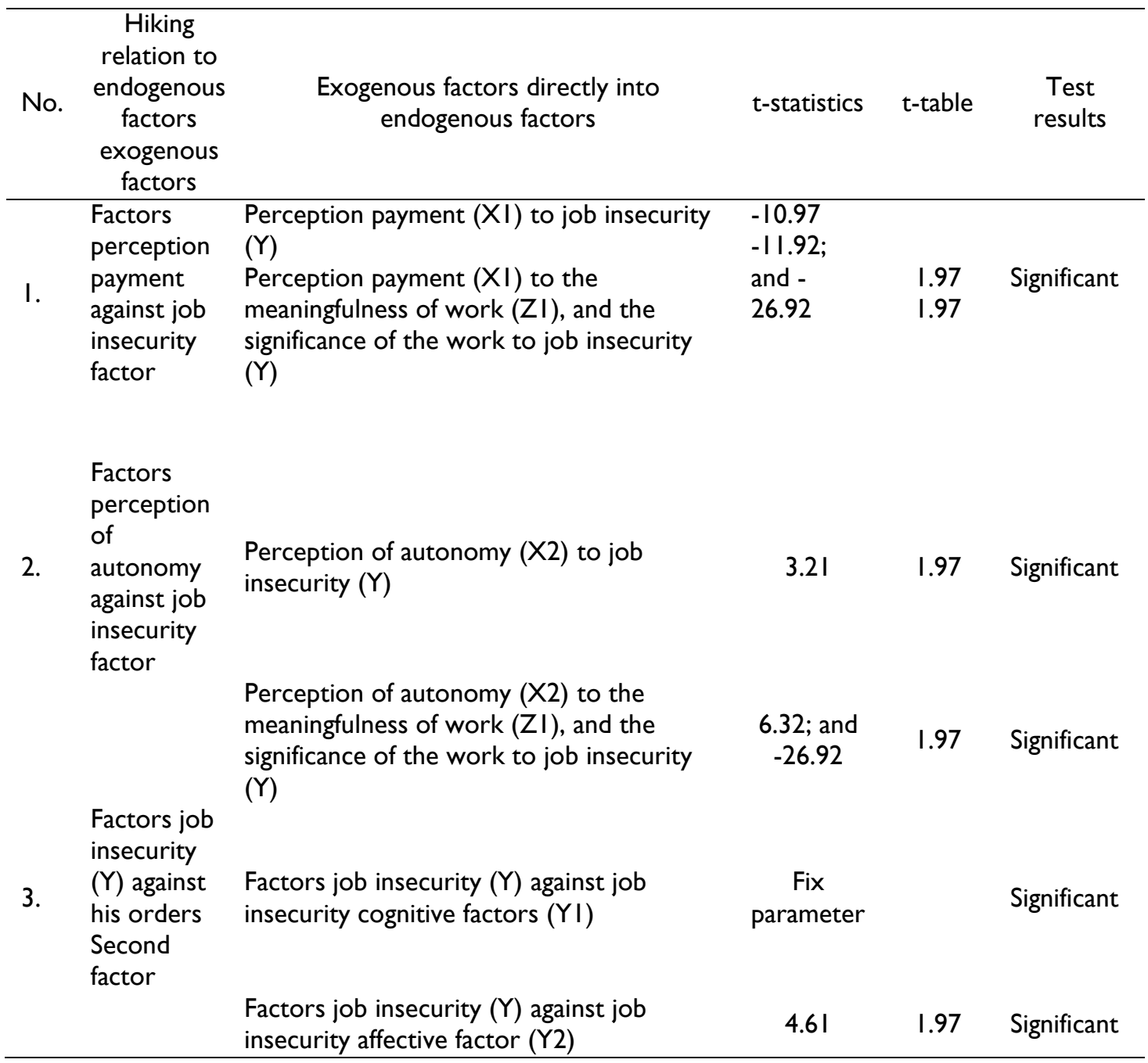

Based on table 9, it is known the relationship between exogenous factors directly to the endogenous factors, it was concluded from the test results are significant of all. This is because the value of t-statistics| the value is greater than t-table. The significant relationship means that the value of the relationship is relatively high influence or strong influence. The conclusion of the above t-test was subsequently used to answer the research hypotheses, more as follows. 
First, there is a significant effect of perception of payment $(X I)$ on job insecurity on physicians ( $\mathrm{Y})$, both directly and indirectly through meaningful work as mediation (ZI). Second, there is a significant influence on the perception of autonomy $(X 2)$ on job insecurity on physicians (Y), both directly and indirectly through meaningful work as mediation (ZI). Third, that significant job insecurity on physicians $(\mathrm{Y})$ is explained by cognitive factors Job Insecurity $(\mathrm{YI})$. Fourth, that significant job insecurity on general practitioners $(\mathrm{Y})$ is explained by the affective factor of Job Insecurity (Y2).After knowing the significance test the effect of the direct relationship between exogenous factors on endogenous factors in the path diagram above. Then do the path diagram analysis using the value of the influence of the relationship path above.

Path diagram the influence of this model is job insecurity in the physician( $\mathrm{Y})$ is directly affected by the perception of payment $(X I)$ directly or indirectly through the meaningfulness of work (ZI), and then also influenced by the perception of autonomy (X2) directly or indirectly through the meaningfulness of work (ZI), and where job insecurity in the physician $(\mathrm{Y})$ is explained by cognitive factors job insecurity $(\mathrm{YI})$ and job insecurity affective factor (Y2).

The following is a picture of the influence values in the path diagram (path diagram) of this model.

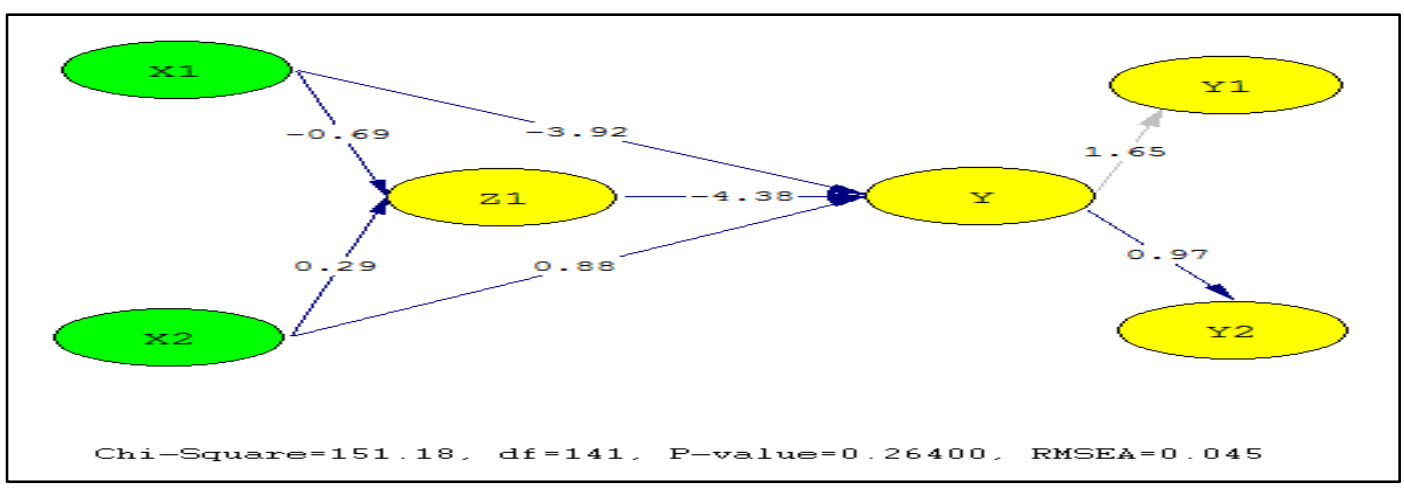

Fig. 6 Value t-statistics on the relationship path between factors

Based on figure 6, we know the value of the effect of exogenous factors on the connectivity of endogenous factors. 
Table 10

The results of testing the influence of exogenous factors on endogenous factors in the relationship pathway

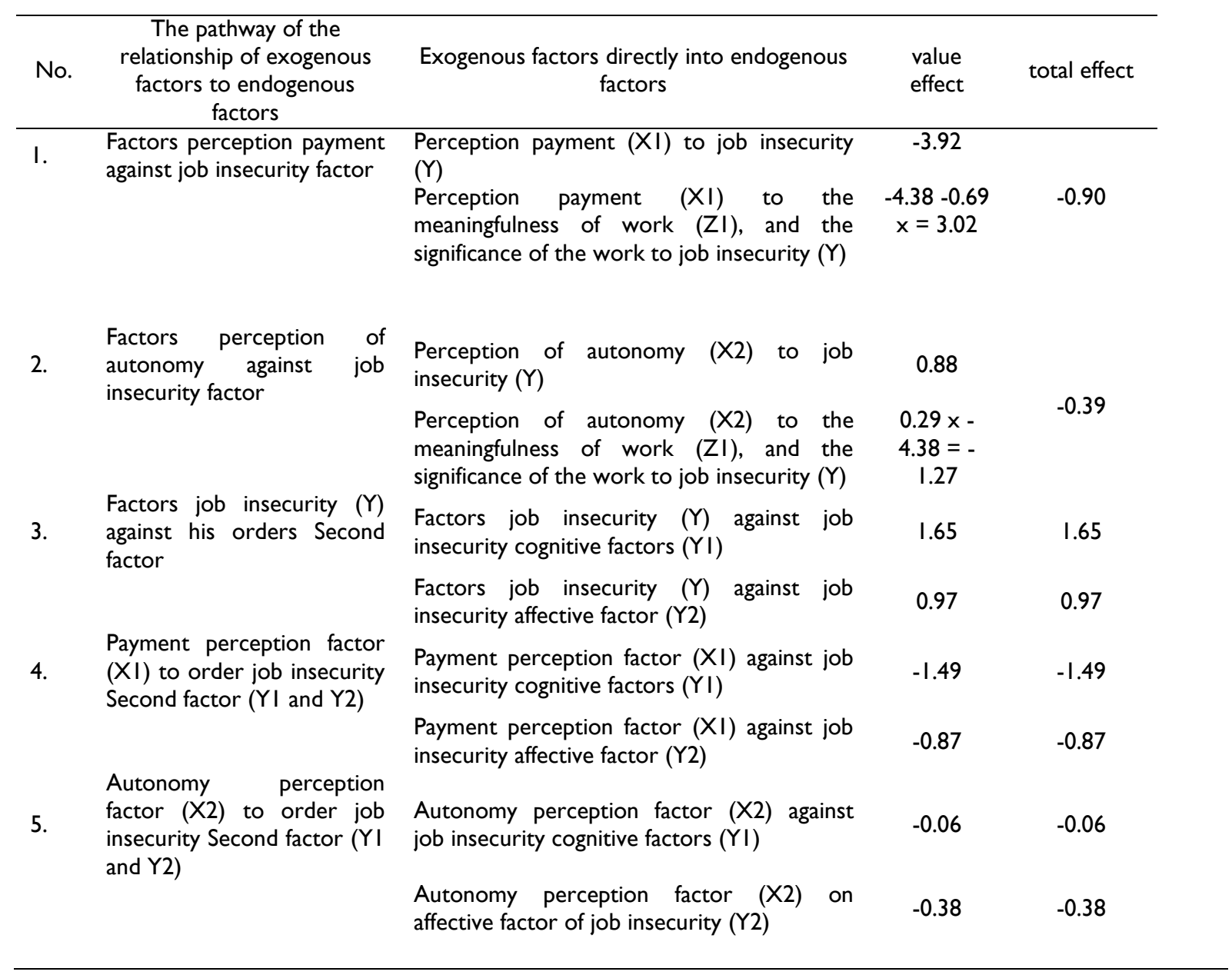

\section{Discussion}

The result of this study reveal some significant relations between exogenous and endogenous variables. According to the table 10, can be interpreted in relation pathways influence the value of exogenous factors on endogenous factors, as follows. The first path, namely the relationship path from the perception factor of payment to the job insecurity factor. The total value of the influence of the first line is in the opposite direction because it is negative, meaning that if the perception factor of payment gets higher then the tendency of the job insecurity factor will be lower or lower.The results of this study are consistent 
with research conducted by Narisada stating that sometimes individuals tend to ignore the income received as long as they feel that their work is meaningful (Narisada,20I6)

The second path, namely the relationship path from the perception factor of autonomy to the job insecurity factor. The total value of the influence of the second path is opposite because it is negative, meaning that if the factor of perception of autonomy gets higher, the tendency of job insecurity factors will be lower. The job insecurity factor on the physicians explained or measured by the cognitive factor job insecurity The factor of job insecurity on the physician is explained or measured by the affective factor of job insecurity. This study supports research previously conducted by Solberg (Solberg et al., 2012; Tyssen, Palmer, Solberg, Voltmer, \& Frank, 20I3), who examined that a factor that was felt to reduce doctor job satisfaction was reduced autonomy. while other research states that the lack of autonomy will make doctors feel powerless to change the situation and this can trigger insecure (Kaplan, 2009).

The third path, namely the relationship path from the perception factor of payment to the cognitive factor job insecurity. The total value of the influence is in the opposite direction because it is negative, meaning that if the perception factor of payment is high then the tendency of cognitive factor job insecurity will decrease. The results of this study are supported by the opinion that if the doctor is cognitively aware that the payment scheme received must be in accordance with his professionalism, then he will tend to be satisfied at work and less insecure (Collier, 20I2).

The fourth path, namely the relationship path from the perception factor of payment to the affective factor of job insecurity. The total value of its influence is in the opposite direction because it is negative, meaning that if the perception factor of payment is high, the tendency of affective factor job insecurity will decrease the results of the study are almost similar to the research conducted by Cossman. In the research conducted it was found that doctors who felt (emotionally) that authority or autonomy was reduced due to the presence of a third party (insurance) would tend to have the intention to leave the organization where 
they worked. The intention to leave the job is one indicator of job insecurity (Rischatsch \& Zweifel, 2013; Street \& Cossman, 2009).

The fifth path, namely the relationship path of the autonomy perception factor to the cognitive factor job insecurity. The total value of the influence is in the opposite direction because it is negative, meaning that if the perception factor of autonomy is high then the tendency of cognitive factor job insecurity will be higher. The results of this study are in line with research which states that the cognitive factors that most play a role in shaping an individual's job satisfaction. the more a person is cognitively aware that he has enough autonomy, the more satisfied with his work and will reduce the sense of insecurity at work (Schlett \& Ziegler, 20I4).

The sixth path, namely the relationship path from the perception factor of autonomy to the affective factor of job insecurity. The total value of its influence is in the opposite direction because it is negative, meaning that if the perception factor of autonomy is high, then the tendency of affective factor job insecurity will be higher.The results of this study support research that has been done in Taiwan, which shows that the factor of work autonomy is an important factor in determining the individual work outcomes. Individuals who feel they have sufficient autonomy tend to be satisfied at work and have less desire to leave their jobs. An autonomy that is considered sufficient work will not trigger insecurity (F. Briscoe et al., 20I3; Lin, Lin, Lin, \& Lin, 20I3).

Job insecurity reflects the extent to which workers/individuals feel their work is threatened, and feel they do not have the power to overcome it. This feeling of threat can be caused by various things, for example, technological advances that can replace human roles. A sense of inadequacy can be caused by conditions that occur outside the control of individuals so that a sense of helplessness arises (Adekiya, 20I5). This is consistent with the results of research that shows Jl's physician tend to increase because they feel unable to control the situation, in this case, due to the impact of the implementation of BPJS. Literature studies also emphasize that job insecurity is one of the triggers of stress caused by an individual's perception of the work environment (Urbanavičiūtè et al., 20I5). Individual perceptions are 
often subjective, although the aspect that is observed is objective conditions. The conclusion of the various definitions is concluded job insecurity is a condition experienced by individuals who feel unsure of the future of their profession, are subjective and the uncertainty arises from observations of a changing work environment.

\section{Conclusion}

Based on the results of path analysis, structural model testing and measurement model above, it can be concluded. Factors payment significantly influences the perception of job insecurity physician, either directly or indirectly through the mediation of the meaningfulness of work. The better perception of the payment will decrease job insecurity physicians. Further factors described perception payment benefit most by the indicator.

Autonomy perception factors significantly influence physician job insecurity age, either directly or indirectly through the mediation of the meaningfulness of work. The better perception of autonomy it will reduce job insecurity physician. Further factor's greatest perception of autonomy described by the interaction time indicator. Job insecurity is based on individual perceptions and interpretations of the work environment. This results in threats that are objective experiences treated as perceptual objects and subjective cognitive processes. In situations faced by general practitioners, changes in the health care system are objective situations that are currently being faced, but the changes can be interpreted differently because the perceptions of different individuals will determine the extent to which changes are perceived as a form of threat or not. In doctors who interpret change as something that is not threatening, then it is likely that they do not experience job insecurity, but the perceived changes threaten the survival of their profession in the future, the individual concerned has the potential to experience job insecurity.

Further payment perceptual factors have a greater influence on job insecurity at a physician compared autonomy perception factor. Compare with other research, the results of research conducted by (Wrzesniewski \& Dutton, 200I) show that someone who feels that 
his job is a form of heart calling, has a higher job satisfaction, feels more free, and does not mind the time and effort involved in working (Steger, Dik, \& Duffy, 20I2).

The ability of a person to be able to find meaningfulness in his work will determine the extent to which he has the potential to experience psychological distress or vice versa, experiencing well-being. The results showed, a physician who received training to find meaningfulness in their work relatively reduced distress, and were more involved in their work (West et al., 2014).

Factors job insecurity felt by the physician larger than explained by cognitive factors affective factors, Where an indicator of cognitive factors biggest perceived job insecurity physician is difficult to get a job. While the indicator of job insecurity affective biggest factor is the stress of the work environment and the reduction in the role of a physician due to complex bureaucracy. Job insecurity is based on individual perceptions and interpretations of the work environment. This results in threats that are objective experiences treated as perceptual objects and subjective cognitive processes. In situations faced by general practitioners, changes in the health care system are objective situations that are currently being faced, but the changes can be interpreted differently because the perceptions of different individuals will determine the extent to which changes are perceived as a form of threat or not. In physician who interprets change as something that is not threatening, then it is likely that they do not experience job insecurity, but the perceived changes threaten the survival of their profession in the future, the individual concerned has the potential to experience job insecurity.

\section{Limitation and Suggestion}

First, the sample for the present study was limited to a physician who works in the health care center. The main limitation was the use of a convenience sampling method, which means respondents may not represent a sufficiently broad sample of a physician. 


\section{References}

Adekiya, A. (2015). Perceived Job Insecurity: Its Individual, Organisational and Societal Effects. European Scientific Journal, I (December), I00-II8. https://doi.org/-ISSN I8577431

Bolanowski, W. (2005). Anxiety about Professional Future Among Young Doctor. International Journal of Occupational Medicine and Environmental Health, I8I8(44), 367374.

Briscoe, F., Doef, M. Van Der, Maes, S., Fernet, C., Austin, S., Trépanier, S.-G., ... Frank, E. (20I3). How do job characteristics contribute to burnout? Exploring the distinct mediating roles of perceived autonomy, competence, and relatedness. European Journal of Work and Organizational Psychology, 22(2), I23-137. https://doi.org/I0.1080/I359432X.201 I.632161

Briscoe, J. P., Henagan, S. C., Burton, J. P., \& Murphy, W. M. (20I2). Coping with an insecure employment environment: The differing roles of protean and boundaryless career orientations. Journal of Vocational Behavior, 80(2), 308-316. https://doi.org/I0.1016/j.jvb.20II.12.008

Chalofsky, N. E. (20I0). Meaningful Workplaces: Reframing How and Where we Work (Ist ed.). San Fransisco: A Wiley Imprint.

Collier, R. (2012). Professionalism: assessing physician behaviour. CMAJ : Canadian Medical Association journal = journal de l'Association medicale canadienne, I84(I2), I349-I350. https://doi.org/I0.I503/cmaj. I09-4240

Emanuel, E. J., \& Pearson, S. D. (20I2). Physician Autonomy and Health Care Reform. JAMA: The Journal of the American Medical Association, 307(4), 367-368. https://doi.org/I0.100I/jama.2012.19

Epstein, R. M., \& Krasner, M. S. (2013). Physician resilience: What it means, why it matters, and how to promote it. Academic Medicine, 88(3), 30I-303. https://doi.org/10.1097/ACM.0b013e318280cffo

Fairlie, P. (20I I). Meaningful Work, Employee Engagement, and Other Key Employee Outcomes: Implications for Human Resource Development. Advances in Developing Human Resources, 13(4), 508-525. https://doi.org/ I0.1 I77/I5234223 I I 43 I679

Gask, L. (2004). Powerlessness, control, and complexity: The experience of family physicians in a group model HMO. Annals of Family Medicine, 2(2), I50-I55. https://doi.org// 0.1370/afm.58

Greenhalgh, L., \& Rosenblatt, Z. (1984). Job insecurity - toward conceptual clarity. Academy of Management Review, 9(3), 438-448. https://doi.org/I0.5465/AMR.1984.4279673

Greenhalgh, L., \& Rosenblatt, Z. (20I4). Evolution Research on Job Insecurity. International Studies of Management \& Organization Evolution of Research on Job Insecurity, 40(May 20I5), 37-4I. https://doi.org/ I 0.2753/IMO0020-8825400 I0 I

Grignon, M., Paris, V., \& Polton, D. (2002). Influence of Physician Payment Methods on the Efficiency of the Health Care System by. Health (San Francisco).

Hashimoto, N. (2006). Professional autonomy. Jmaj, 63(4), 608-6I5. Diambil dari http://www.ncbi.nlm.nih.gov/pubmed/21077385

Kaplan, D. (2009). Determinants of job satisfaction and turnover among physicians., I-56. Diambil dari papers3://publication/uuid/CD ICE6DD-2FCI-4639-A6 I I-59I 556E66CA7

Keim, A. C., Landis, R. S., Pierce, C. A., \& Earnest, D. R. (20I4). Why do employees worry about their jobs? A meta-analytic review of predictors of job insecurity. Journal of 
Occupational Health Psychology, 19(3), 269-290.

https://doi.org/http://dx.doi.org// 0.1037/a0036743

Khullar, D., Choksi, D. A., \& Kocher, R. (20I5). Behavioral Economics and Physician Compensation - Promise and Challenges. The New England journal of medicine, 372(24), 2279-228I. https://doi.org/I0.1056/NEJMp I503428

Konig, C. J., Debus, M. E., Hausler, S., Lendenmann, N., \& Kleinmann, M. (2010). Examining occupational self-efficacy, work locus of control and communication as moderators of the job insecurity--job performance relationship. Economic and Industrial Democracy, 3 I(2), 23 I-247. https://doi.org/I0.I I77/0 I4383 IX09358629

Konrad, T. R., Williams, E. S., Linzer, M., McMurray, J., Pathman, D. E., Gerrity, M., ... William E. Scheckler, Judith Van Kirk, E. R. and J. D. (1999). Measuring Physician Job Satisfaction in a Changing Workplace and a Challenging Environment. Medical Care Vol. 37, No. I I, I I740 I I82. https://doi.org/I0.1097/00005650-1999I 1000-000 I0

Kuusio, H., Heponiemi, T., Aalto, A.-M. M., Sinervo, T., \& Elovainio, M. (20I2). Differences in well-being between GPs, medical specialists, and private physicians: The role of psychosocial factors. Health Services Research, 47(I PART I), 68-85. https://doi.org/10.1III/j.1475-6773.2011.01313.x

Lin, B. Y., Lin, Y.-K., Lin, C.-C., \& Lin, T. (20I3). Job autonomy, its predispositions and its relation to work outcomes in community health centers in Taiwan. Health Promotion International, 28(2), I66-I77. https://doi.org/I0.1093/heapro/dar09|

Lips-Wiersma, M., Wright, S., \& Dik, B. (2016). Meaningful work: differences among blue-, pink-, and white-collar occupations. Career Development International, 2I(5), 534-55I. https://doi.org/I0.1 108/CDI-04-2016-0052

Loi, R., Lam, L. W., Chan, K. W., \& Wai, K. (20I2). Coping with Job Insecurity: The Role of Procedural Justice, Ethical Leadership and Power Distance Orientation. Journal of Business Ethics, 108, 36 I-372. https://doi.org/I0.1007/s I055I-0I I-1095-3

Martínez, G., Cuyper, N. D. E., \& De Witte, H. (2010). Review of the job insecurity literature: The case of Latin America. Avances en Psicología Latinoamericana, 28(2), 194204. Diambil dari http://www.scielo.org.co/pdf/apl/v28n2/v28n2a4.pdf

Michaelson, C., Pratt, M. G., Grant, A. M., \& Dunn, C. P. (20I4). Meaningful Work: Connecting Business Ethics and Organization Studies. Journal of Business Ethics, 12 I (I), 77-90. https://doi.org/I0.1007/s I055I-013-1675-5

Narisada, A., \& Schieman, S. (2016). Underpaid but Satisfied: The Protective Functions of Security. Work and Occupations, 43(2), 215-255. https://doi.org/I0.1 I77/07308884I5625332

Pienaar, J., De Witte, H., Hellgren, J., \& Sverke, M. (20I3). The Cognitive/Affective distinction of job insecurity: Validation and differential relations. Southern African Business Review, I 7(2), I-22.

Ran, L. M., Luo, K. J., Wu, Y. C., Yao, L., \& Feng, Y. M. (2013). An analysis of china's physician salary payment system. Journal of Huazhong University of Science and Technology - Medical Science, 33(2), 309-3 I4. https://doi.org/I 0.1007/s I I 596-0 I 3-I I I6-9

Richter, A., Näswall, K., Bernhard-Oettel, C., \& Sverke, M. (20I3). Job insecurity and wellbeing: The moderating role of job dependence. European Journal of Work and Organizational Psychology, (August), I-14. https://doi.org/10.1080/1359432X.2013.80588I

Rischatsch, M., \& Zweifel, P. (20I3). What do physicians dislike about managed care? 
Evidence from a choice experiment. European Journal of Health Economics, 14(4), 60I613. https://doi.org/10.1007/s 10198-012-0405-8

Schlett, C., \& Ziegler, R. (20I4). Job emotions and job cognitions as determinants of job satisfaction: The moderating role of individual differences in need for affect. Journal of Vocational Behavior, 84(I), 74-89. https://doi.org/I0.1016/j.jvb.2013.1 I.005

Sochos, A., Bowers, A., \& Kinman, G. (20I2). Work stressors, Social Support, and Burnout in Junior Doctors: Exploring Direct and Indirect Pathways. Journal of Employment Counseling, 49(June), 62-73. https://doi.org//0.1002/j.216I-1920.2012.00007.x

Solberg, I., Rø, K., Aasland, O., Gude, T., Moum, T., Vaglum, P., \& Tyssen, R. (20I2). The impact of change in a doctor's job position: a five-year cohort study of job satisfaction among Norwegian doctors. BMC Health Services Research, I2(I), 4I.

https://doi.org/I0.I I86/I472-6963-I2-4I

Staufenbiel, T., \& König, C. J. (20II). An Evaluation of Borg's Cognitive and Affective Job Insecurity Scales. International Journal of Business and Social Science, 2(20).

Steger, M. F., Dik, B. J., \& Duffy, R. D. (20I2). Measuring Meaningful Work: The Work and Meaning Inventory (WAMI). Journal of Career Assessment, 20(3), 322-337.

https://doi.org/10.1 I77/10690727II436160

Street, D., \& Cossman, J. (2009). Autonomy, Satisfaction and Physician Burnout, (I).

Tomioka, K., Morita, N., Saeki, K., Okamoto, N., \& Kurumatani, N. (20I I). Working hours, occupational stress and depression among physicians. Occupational Medicine, $6 I$ (3), 163-170. https://doi.org//0.1093/occmed/kqr004

Tyssen, R., Palmer, K. S., Solberg, I. B., Voltmer, E., \& Frank, E. (20I3). Physicians' perceptions of quality of care, professional autonomy, and job satisfaction in Canada, Norway, and the United States. BMC Health Services Research, I3(I), 516. https://doi.org/I0.1186/I472-6963-13-516

Urbanavičiūtè, I., Bagdžiūnienè, D., Lazauskaitè-Zabielskè, J., Elst, T. Vander, \& De Witte, H. (20I5). The Role of Career Factors in Qualitative and Quantitative Job Insecurity: A Study in Different Organizational Contextz. International Journal of Psychology: A Biopsychosocial Approach, 16. https://doi.org// 0.7220/2345-024X.16.2

Vander Elst, T., De Witte, H., \& De Cuyper, N. (20I4). The Job Insecurity Scale: A psychometric evaluation across five European countries. European Journal of Work and Organizational Psychology, 23(3), 364-380.

https://doi.org/10.1080/I359432X.2012.745989

Warren, M. G., Weitz, R., \& Kuhs, S. (1999). The Impact of Managed Care on Physicians, 24(2), 44-56.

Wrzesniewski, A., \& Dutton, J. E. (200I). Crafting a job: Revisioning employees as active crafters of their work. Academy of Management Review, 26(2), I79-20I. https://doi.org/I0.5465/AMR.200 I.43780 I I

Yeoman, R. (20I4). Conceptualising Meaningful Work as a Fundamental Human Need. Journal of Business Ethics, I 25(2), 235-25 I. https://doi.org/I0.1007/s I055 I-0 I3-I894-9

Zwack, J., \& Schweitzer, J. (20I3). If Every Fifth Physician Is Affected by Burnout, What About the Other Four? Resilience Strategies of Experienced Physicians. Academic Medicine, 88(3), 382-389. https://doi.org/I0.1097/ACM.0b0I3e31828I696b 